\title{
Pequeña historia de un proyecto utópico: el Movimiento del Nuevo Cine y Video Boliviano y su Revista Imagen.
}

\section{Brief Story of a Utopian Project: The Movement of the New Bolivian Cinema and Video and its Revista Imagen.}

\begin{abstract}
Resumen
En el marco de una investigación más amplia que releva, describe y analiza las prácticas de producción audiovisual en La Paz, Bolivia, entre 1978 y 1989, el presente trabajo se centra en historiar el proyecto editorial Imagen: una revista de cine que publicó el Movimiento del Nuevo Cine y Video Boliviano durante la segunda mitad de la década del ochenta. Sin tradición local en lo que refiere a publicaciones dedicadas al cine, Imagen fue una iniciativa autogestionada y autofinanciada, que funcionó con una frecuencia y formato variable, y sirvió como foro de discusión sobre temas específicos del quehacer local, vehículo de difusión de actividades del Movimiento, micro espacio de formación, medio de circulación de convocatorias y concursos, y herramienta de articulación entre distintas propuestas.

El trabajo explica su devenir histórico, describe sus caracteres generales y perfil editorial, da cuenta de los actores intervinientes y sus formas de organización, y señala las condiciones de posibilidad, alcances y limitaciones del proyecto.
\end{abstract}

Palabras claves

Video Boliviano; Cine Boliviano; Revista Imagen; televisión; Movimiento del Nuevo Cine y Video

Boliviano

\begin{abstract}
In the context of a more extensive research that reveals, describes and analyses the audiovisual production practices in La Paz, Bolivia, between 1978 and 1989, the present work focuses on the chronicle of the editorial project Imagen: a film magazine published by the Movement of the New Bolivian Film and Video during the second half of the eighties. With no local tradition of film publications, Imagen was a self-supporting and self-financed
\end{abstract}


CATEDRAL Tomada: Revista de crítica literaria latinoamericana / Journal of Latin American Literary Criticism Pequeña historia de un proyecto utópico: el Movimiento del Nuevo Cine y Video Boliviano y su Revista Imagen

initiative, which operated with a changeful frequency and format, and served as a forum for discussion on specific issues of local work, acted as a vehicle for dissemination of the Movement activities, a micro-training space, a medium of circulating calls and contests, and a tool for articulating different proposals.

The work explains the publication's historical evolution, describes its general characteristics and editorial profile, gives an account of the intervening actors and their forms of organization, and indicates the conditions of possibility, accomplishment and limitations of the project.

Keywords Bolivian Video, Bolivian Cinema, Imagen Magazine, television, Movement of the New Bolivian Film and Video.

\section{Sumario (a manera de introducción)}

En buena medida el trabajo del/la historiador/a de cine latinoamericano es enfrentarse con vacíos, lagunas o zonas de vacancia en materia de investigación y desde allí interrogar e interrogarse: repensar genealogías, trayectorias, prácticas e imágenes, y desmontar prejuicios y doxas que obturen el análisis. La década del ochenta en Bolivia no ha concitado prácticamente interés y con frecuencia se ha subestimado, apresuradamente, la calidad de la producción de la época minimizando a su vez las evidentes transformaciones que sufrió el ámbito audiovisual en aquellos años, en paralelo a un cambio drástico de la fisonomía del paisaje económico, social y político nacional. Justamente, en pos de la problematización del período, nos detendremos en un proyecto - también olvidado- que es a la vez testimonio y documento de las prácticas audiovisuales emergentes, las formas de reorganización del campo, sus protagonistas, obras, discursos, discusiones, sueños y dilemas.

El Movimiento del Nuevo Cine y Video Boliviano (MNCVB) fue una heterogénea plataforma de trabajo que, desde mediados de la década del ochenta, congregó a cineastas, videastas, técnicos, comunicadores sociales, educadores y artistas, bajo un impulso reactivador y revitalizador del sector. A pesar de los magros fondos con que contaba la entidad, los y las jóvenes que la compusieron no sólo se dedicaron a la producción y amplia difusión de materiales, sino que 
además crearon y sostuvieron una herramienta de comunicación y socialización de aprendizajes y pensamiento crítico: la Revista Imagen.

Sin tradición local en lo que refiere a publicaciones dedicadas a la cultura y al cine, Imagen fue un proyecto editorial utópico, autogestionado y autofinanciado, que funcionó hasta los primeros años de la década del noventa. ${ }^{1}$ Con una frecuencia y formato variables, la revista sirvió como foro de discusión sobre temas específicos del quehacer audiovisual local, vehículo de difusión de actividades del Movimiento dentro y fuera de Bolivia, micro espacio de formación, medio de circulación de convocatorias, llamados a concursos y becas, y herramienta de articulación entre distintas propuestas.

\section{Filiaciones}

Para comprender de forma adecuada la "pequeña" — por breve- pero valiosa historia de la Revista Imagen en el marco de una diacronía más amplia y sin desatender las complejidades de su sincronía-; es necesario dar cuenta del estado del campo de estudios y publicaciones sobre cine en Bolivia entre fines de la década del setenta y primeros ochenta. Ese campo configura simultáneamente: uno de los factores o condiciones de posibilidad de emergencia de la revista, el territorio en el que se sitúa el emprendimiento y un espacio intelectual al que se interpela, con el que interactúa y al que nutre.

Luego de décadas de silencio y mínima actividad editorial en lo que refiere a análisis, crítica e historia del audiovisual vernáculo, entre la segunda mitad de los setenta y los primeros ochenta se advierte un fenómeno paradójico:

${ }^{1}$ Las publicaciones más recordadas fueron: la ya antológica revista del grupo teatral "Nuevos Horizontes" que con interrupciones se editó desde los cincuentas; la revista de cine "Warawara", publicada después de la Revolución de 1952 (sólo un número); el boletín cinematográfico "Estrenos", editado a comienzos de los sesenta por el Grupo Kollasuyo Films, formado por Jorge Sanjinés, Oscar Soria y Ricardo Rada (diez números de extensión breve: 8 carillas); la revista "Escena" en los setenta (dos números); la revista "Film-Historia" en mayo de 1978 (sólo un número) y, ya en los noventa posterior al caso que nos ocupa, la Revista de Artes Escénicas "El Tonto del Pueblo" del grupo Teatro de los Andes (cinco números). 
CATEDRAL TOMADA: Revista de crítica literaria latinoamericana / Journal of Latin American Literary Criticism Pequeña historia de un proyecto utópico: el Movimiento del Nuevo Cine y Video Boliviano y su Revista Imagen

en palabras del historiador Pedro Susz, si bien no se produce tanto "[...] se escribe mucho sobre cine, se debate mucho sobre cine" (Entrevista personal).

La primera colección de libros especializada que tuvo Bolivia fue la que imprimiera desde 1975 la Editorial Don Bosco: en formato de bolsillo y a precios muy económicos, "Cuadernos de cine" — en su mayoría escritos por el crítico, poeta, cineasta, docente y militante por los DD.HH. Luis Espinal- se agotó rápidamente y fue un material insoslayable para pensar y debatir la producción local, ya sea en la crítica (gráfica y radial) como en los ámbitos de cine clubes. Su temática era muy amplia e iba desde los géneros, el lenguaje y las narrativas cinematográficas, hasta la historia del cine latinoamericano, la sociología, la simbología y la psicología del cine, las interacciones y tensiones con la TV, y las formas de la censura. En un país que no contó con ninguna escuela de cine o carrera de comunicación hasta principios de los ochenta, estos textos terminaron siendo una suerte de dispositivo de formación-informal.

A nivel institucional, la Cinemateca Boliviana —entidad privada sin fines de lucro, creada en 1976 y dedicada al reservorio de imágenes en movimiento y exhibición cinematográfica- publicó con regularidad una serie de folletos informativos tanto de sus ciclos, como respecto de la historia del cine local. Esas pequeñas notas explicativas y de opinión sobre los films proyectados señalaba la tesonera vocación pedagógica y divulgativa de un organismo prácticamente sin fondos, para el cual si bien el emprendimiento demandaba un esfuerzo económico, constituía más poderosamente una necesidad vital: la de contribuir a la formación crítica y reflexiva del público cinematográfico boliviano.

Por su parte, los periodistas y críticos obtuvieron en esos años mayor espacio en la prensa gráfica y radial y, aunque sin continuidad, hacia 1979 se organizaron gremialmente en la CRIBO (Asociación de Críticos Bolivianos) creada: "Con el objeto de "contribuir al fortalecimiento de una corriente de cine desmitificador, desalienador, que contribuya a esclarecer la realidad nacional [...] el público boliviano necesita de una orientación que le permita adquirir sus 
propios instrumentos de crítica para poder ver cine como un hecho cultural y no de mera evasión" (Gumucio Dagron, Historia 315).

Justamente, Carlos Mesa — uno de los referentes de la crítica y parte de la gestión de la Cinemateca- compiló y coescribió en 1979 un sustancioso volumen de autoría colectiva titulado "Cine boliviano: del realizador al crítico": un trabajo que recoge aportes para la historia del cine vernáculo, críticas a diversos films, entrevistas y, lo que no es menor, las discusiones que en ese momento se desarrollaban en torno al campo audiovisual y que protagonizaron diversos actores - como su título indica, desde los realizadores a los críticos. Poco después, en 1979 y 1980 el Grupo Ukamau y Jorge Sanjinés publicaron la primera y segunda edición de "Teoría y Práctica de un cine junto al pueblo": un texto fundamental que reúne reflexiones y textos teóricos basados en la experiencia de casi veinte años de trabajo y que servirá de insumo conceptual y creativo no sólo para el campo local, sino regional. Habiendo sufrido la pérdida irreparable de Luis Espinal — secuestrado, torturado y asesinado con brutalidad por los esbirros del militar golpista Luis García Meza-, Carlos Mesa (1982) y Alfonso Gumucio Dagron $(1981,1986)$ escribieron libros de homenaje que iluminan la trayectoria y el pensamiento intelectual del periodista y maestro de la crítica. En esos años se conocieron también las dos emblemáticas e insoslayables historias del cine boliviano escritas por Gumucio Dagron (1982) y Mesa $(1985){ }^{2}$ y el no menos fundamental ensayo sobre los consumos y las prácticas de recepción cinematográfica en Bolivia entre 1975 y 1984 de Pedro Susz (1985), donde reflexiona sobre la hegemonía norteamericana en las pantallas locales y diagnostica las consecuencias del impacto creciente de la cultura masiva en el imaginario popular urbano.

${ }^{2}$ En comunicación personal, Gumucio Dagron recordó que hasta 1980 la única historia del cine boliviano era la suya: "[...] que estaba ya en la imprenta cuando vino el golpe de julio 1980. Yo estaba exiliado en la Embajada de México y vino el Sr. Flores, de la Editorial Los Amigos del Libro, pidiéndome que borrara las referencias a Luis Espinal y a Marcelo Quiroga Santa Cruz, para poder publicar el libro inmediatamente, pero me negué, y por eso el libro salió recién en 1982 y 1983 (la edición mexicana)". 
CATEDRAL Tomada: Revista de crítica literaria latinoamericana / Journal of Latin American Literary Criticism Pequeña historia de un proyecto utópico: el Movimiento del Nuevo Cine y Video Boliviano y su Revista Imagen

En suma: puede advertirse que, como nunca antes en la historia del cine boliviano, desde la caída de la dictadura de Hugo Bánzer en 1978 y la apertura del conflictivo proceso transicional (1978-1982), aún en medio de la inestabilidad político-institucional y la carestía económica, con diversos formatos pero con un registro argumentativo y polémico similar, la producción bibliográfica sobre cinematografía nacional crece exponencialmente. Esto nos conduce a cuatro corolarios. El primero tiene que ver con la consolidación de un grupo de intelectuales y estudiosos del cine vernáculo que producen conocimiento y cuentan con cierto respaldo o reconocimiento social basado, por lo general, en una trayectoria práctica y pública previa ligada al cineclubismo, la prensa gráfica y radial, y la gestión cultural. El segundo, que ese grupo de hombres y mujeres dedicados al estudio de la imagen en movimiento encuentra interlocutores válidos: es decir, lectores y cinéfilos que consumen este tipo de literatura —en líneas generales económica y conceptualmente accesible. El tercer corolario confirma la preeminencia y relevancia de la ciudad de La Paz sobre el resto de las ciudades departamentales en lo que refiere a la producción escrita, en sintonía con una serie de variadas instituciones, asociaciones, experiencias y prácticas de difusión y consumo cinematográfico activas todas en la ciudad capital. El último, síntesis de todos los anteriores, nos hace evidente la razón de confianza que los y las jóvenes videastas tuvieron a la hora de sacar una revista periódica: en un escenario de creciente productividad resultó plausible editar una publicación que contara no sólo con un segmento lector específico — que ya venía formándose con los textos mencionados-, sino con una serie de interlocutores empáticos e idóneos con los cuales polemizar — los intelectuales mayores. Amparados y estimulados por esta serie de emprendimientos, los jóvenes del MNCVB alzaron su voz-escrita y convocaron a la generación anterior para, productivamente, discutir el pasado, el presente y el futuro práctico y teórico del audiovisual boliviano. 
CATEDRAL TOMADA: Revista literaria latinoamericana / Journal of Latin American Literary Criticism María Gabriela Aimaretti

\section{EI MNCVB}

Inspirados en las tareas de cineclubismo desarrolladas por Luis Espinal en la década del '70 y su perspectiva ético-política; con la formación recibida en el Taller de Cine de la Universidad Mayor de San Andrés; tomando los apoyos de la joven pero emprendedora Cinemateca Boliviana, la Universidad y su televisión; nutridos por las lecturas de la bibliografía local; frente a la ausencia completa de una política comunicacional estatal y legislación acorde, y preocupados por la hegemonía creciente de las empresas de televisión privada que facilitaban la penetración cultural massmediática de los EE.UU.; un diverso grupo de jóvenes decidió aglutinar esfuerzos y fundar en La Paz en febrero de 1984 el Movimiento del Nuevo Cine y Video Boliviano. ${ }^{3}$ Raquel Romero, Iván Sanjinés, Gustavo Cardoso, Liliana De la Quintana, Alfredo Ovando, Francisco Cajías, María Eugenia Muñoz, Jean Claude Eiffel, María Teresa Flores, Marcos Loayza, Néstor Agramont y Eduardo López, entre otros y otras, insuflaron nueva vida a la escena audiovisual y fueron sus protagonistas más activos: mientras contribuían a la formación y desarrollo del Movimiento, cada cual llevaba adelante un proyecto propio - individual, grupal, o colectivo.

Con una comisión directiva elegida por democracia directa, el MNCVB tuvo una estructura flexible y funcionó de manera autogestionada, asamblearia y horizontal bajo un estatuto, similar a un organismo sindical. Entrelazados generacionalmente, afines a un progresismo de izquierda y entusiasmados por un nuevo tiempo democrático, reuniendo de forma no jerárquica a productores, realizadores y técnicos de cine, video y TV, este colectivo se creó con la necesidad de organizar y unificar en un mismo frente a los diversos miembros del sector alrededor de la:

\footnotetext{
${ }^{3}$ En el primer Boletín del Movimiento (1986) figura que los primeros contactos para formar el Movimiento se desarrollaron a fines de 1983, mientras que en el $N^{\circ} 3$ (marzo-abril 1987), figura un breve documento donde se fecha el inicio de la entidad en febrero de 1984.
} 
CATEDRAL TOMADA: Revista de crítica literaria latinoamericana / Journal of Latin American Literary Criticism Pequeña historia de un proyecto utópico: el Movimiento del Nuevo Cine y Video Boliviano y su Revista Imagen

[...] producción de materiales audiovisuales que revaloricen nuestra cultura y reflejen la problemática nacional, frente a la permanente alienación de que somos objeto los bolivianos a través de los Canales de televisión y otros circuitos masivos de comunicación. Ante esta necesidad imperiosa de defensa cultural, el MNCVB considera que la lucha es nacional. (MNCVB, Movimiento 46)

Sus fondos fueron propios, sosteniéndose con el aporte de todos los miembros y el trabajo voluntario, algunas donaciones de organizaciones no gubernamentales y en menor medida con la recaudación de las exhibiciones públicas. Programáticamente se recuperaba el espíritu solidario y el sentido social del cine político del período previo, pero entendiendo que:

[...] el video es utilizado como un medio de acción para informar, movilizar y organizar un diálogo socio-cultural y político entre diversos sectores de la sociedad, apropiándonos del medio y la tecnología que en ningún momento son neutrales, pero que podemos utilizarlos para nuestros propios fines y objetivos. Problemas como la crisis económica, la deuda externa, el rescate de nuestras etnias y culturas son abordados por los videastas del Tercer Mundo, dándole al video un carácter netamente alternativo. (Romero y De la Quintana 56)

El Movimiento se centró en dos tareas fundamentales: fomentar la realización audiovisual con una temática cercana a problemáticas populares y locales, y dinamizar la difusión y exhibición. Un instrumento de fortalecimiento institucional que además se constituyó como herramienta de trabajo, dispositivo de formación, vehículo de información y reconocimiento, fue la Revista Imagen. "Utopía pura" y "proyecto heroico" como lo recordaron varios integrantes entrevistados, fue parte del quehacer cultural del Movimiento: 
CATEDRAL TOMADA: Revista literaria latinoamericana / Journal of Latin American Literary Criticism María Gabriela Aimaretti

[...] en estos momentos en que el país se debate en una profunda crisis económica y social. Olvidarse de la cultura, es olvidarse de nuestro asidero como país y como pueblo. Es olvidarse de nuestras raíces y nuestras necesidades expresivas. Por esto, el Movimiento del Nuevo Cine y Video Boliviano sigue, más firme que nunca, en lo que hemos denominado la "resistencia cultural" [...] Un largo camino nos espera, recorrerlo con honestidad, recuperando con las imágenes nuestra historia y nuestra identidad como pueblos es una obligación impostergable [...]. (Romero, 1986: un fructífero 21, 24)

En efecto, sostenemos que la revista fue una forma concreta con que el MNCVB intervino políticamente tanto en la esfera pública, como en el sector audiovisual: una manera en que tradujo su responsabilidad y compromiso con el presente en crisis no sólo como expresión de resistencia cultural (defensiva) sino como propuesta cultural (ofensiva). Como iremos viendo, lo hizo discutiendo en profundidad los alcances de la estandarización de la imagen y su relación con los imaginarios locales; denunciando con constancia la ausencia de una legislación adecuada que protegiera y fomentara el espacio audiovisual nacional e irradiando posicionamientos críticos al manejo comercial de los medios masivos de comunicación. Simultáneamente visibilizó nuevas formas de organización y trabajo colectivo hasta ese momento inéditas que demostraban que era posible producir aún en un contexto desfavorable, dió a conocer propuestas estéticas y comunicativas emergentes a nivel nacional y regional que no tenían espacio de divulgación en los medios masivos y propuso estrategias de revitalización para la producción cinematográfica. Fue una plataforma de consolidación identitaria del Movimiento que reforzó su credibilidad y prestigio, un vehículo de sensibilización social respecto de problemas concretos como la necesidad de una Ley Nacional de Cine, la perjudicial saturación de canales de televisión privada y de producciones importadas; y una vía de conexión con otros espacios audiovisuales de la región en procura de romper con el aislamiento mediterráneo. 
CATEdRal Tomada: Revista de crítica literaria latinoamericana / Journal of Latin American Literary Criticism Pequeña historia de un proyecto utópico: el Movimiento del Nuevo Cine y Video Boliviano y su Revista Imagen

\section{La Revista Imagen}

\section{Formas de papel para un universo propio}

La revista tuvo once números con diferentes formatos y regularidad variable, entre julio de 1986 y agosto de $1991 .{ }^{4}$ Debe tenerse en cuenta que esta "inestabilidad" — en sus tiempos y formas- respondía fundamentalmente a cuestiones económicas y organizativas de difícil sorteo para una entidad independiente. Se financió con el aporte de los miembros y algunos pequeños auspicios de comercios amigos ${ }^{5}$, la UMSA, la Cinemateca Boliviana, el Grupo Ukamau y el diario católico "Presencia". ${ }^{6}$ En relación a la financiación Jean Claude Eiffel aporta el siguiente dato complementario: "Tomamos el apoyo de unos amigos chilenos exiliados que tenían una imprenta y ellos la imprimían. Nadie cobraba nada [...] se imprimían 500 ejemplares". ${ }^{7}$ La venta a precio de costo - que también servía para cubrir el proyecto- se realizaba, por lo general, personalmente o como algunos recordaron "de forma militante", frente a la Cinemateca, la facultad, algunos bares y centros culturales.

Inicialmente, lo que salió como publicación de difusión del Movimiento fue un boletín fotocopiado de 12 carillas titulado "Boletín del Nuevo Cine y Video. Imagen” (julio de 1986). Allí se hacía un breve repaso de los tres años de la entidad, sus logros y agenda pendiente; se relevaba lo sucedido en el Coloquio "Perspectivas del cine y el video en Bolivia", diagnosticando el estado de la

${ }^{4}$ Los primeros cuatro números, tuvieron un pequeño formato. Desde el $\mathrm{N}^{\circ} 5$ al 7 un formato carta, con mayor cantidad y calidad de imágenes y anuncios publicitarios. Los números 8,9 y 10 salieron como suplemento del diario de gran tirada "Presencia". En el No 11 se vuelve al formato carta.

5 Entre otros: estudios e insumos de fotografía, insumos de video y proyectores, papelería e impresiones, productoras, galerías de arte, marquería, editoriales, cursos de computación, el Goethe Institut, y Radio Color San Gabriel quien respaldó la revista desde el $N^{\circ} 3$ con publicidad a página entera en la contratapa.

${ }^{6}$ Espinal trabajó durante muchos años en "Presencia" hasta que fue despedido a causa de la censura.

${ }^{7}$ Entrevista personal, 30 de julio 2015. 
producción y su relación de tensión y competencia con la TV privada - tema recurrente a lo largo de toda la revista-; se daba cuenta de la intervención del cine boliviano en festivales tercermundistas y se reproducía un convenio establecido con la Asociación de Cineastas del Ecuador. En la contratapa del Boletín se anunciaba un ciclo de cine "Por la Paz y la Justicia Social" en el marco del Año Internacional por la Paz (el Movimiento era parte del Comité Boliviano por la Paz y la Democracia). Ninguna nota iba firmada: así, todo el Boletín quedaba bajo responsabilidad del Comité Ejecutivo de la entidad, cuya secretaria era Raquel Romero.

Si bien esta breve, artesanal y modesta publicación concretó la necesidad del colectivo por tener un órgano de información, divulgación de sus lineamientos, preocupaciones políticas y aspiraciones latinoamericanistas; su extensión y formato no lo satisfizo por completo. De ahí que entre mediados y fines de ese mismo año, el Movimiento repensara íntegramente la publicación: fue entonces que consiguió pequeños auspiciantes y colaboradores, y se lanzó a una empresa más ambiciosa que incluyó notas y artículos diversos, y entrevistas a referentes del área audiovisual.

Imagen contó con un comité de redacción que primeramente conformaron: Jean Claude Eiffel, Juan Fernando Reyes, Iván Sanjinés, Gustavo Cardoso y Marcos Loayza. Allí se discutían los lineamientos, secciones de la publicación y el editorial; pero además se pensaban posibles colaboradores. "¡Había que perseguir a la gente para que escribiera!" recordaron entre risas varios miembros del Movimiento, quienes destacaron que era muy complicado lograr que cada número tuviera distintos columnistas. Con todo, merece la pena subrayarse, entre los fieles y filosamente agudos cómplices del Movimiento y la revista, a Pedro Susz, quien contribuyó en buena parte de las ediciones y cuando pudo ayudó a encender la polémica en pos de enriquecer la reflexión y el análisis crítico y autocrítico dentro del sector — de hecho su pluma figura en el primer y último número. 
CATEdRal Tomada: Revista de crítica literaria latinoamericana / Journal of Latin American Literary Criticism Pequeña historia de un proyecto utópico: el Movimiento del Nuevo Cine y Video Boliviano y su Revista Imagen

Autodesignada como la "revista boliviana de cine y video", el primer número de Imagen salió a fines de 1986 con 45 carillas, correspondiendo a la edición de noviembre-diciembre. ${ }^{8}$ Explicitando la dificultad material de iniciar una publicación sustentable sobre el ámbito cultural, e inscribiendo insistentemente la práctica audiovisual dentro del quehacer nacional, en el primer editorial se lee:

Nuestra mayor preocupación para iniciar un espacio abierto a la actividad cinematográfica tiene su raíz en la necesidad de incentivar la reflexión teórica sobre el quehacer audiovisual, la búsqueda creativa y la paulatina construcción de un lenguaje cinematográfico que responda a nuestra propia realidad. Necesitamos encontrar los canales para expresarnos, crear nuestros propios espacios para plantear nuestras urgencias, para hablar libremente sobre la postergación de nuestra actividad que día a día está más relegada y, en fin, se hacía necesario escuchar la voz de productores y realizadores nacionales, críticos y teóricos de la comunicación en un punto de encuentro. (Imagen, Editorial 11 )

Más orgánica, extensa y organizada en sus contenidos que el anterior Boletín, la revista — planteada originalmente con periodicidad bimestral- tenía algunas secciones fijas que se iban combinando número a número dependiendo de la coyuntura que se estuviera atravesando en el campo local y latinoamericano, y la cantidad de colaboradores con los que se contara. ${ }^{9}$ No se observa una estructura

${ }^{8}$ El segundo número corresponde a enero-febrero de 1987 (57 carillas); el tercero a marzo-abril de 1987 (57 carillas); el cuarto a septiembre-octubre de 1987 (61 carillas), el quinto a diciembre 1988-enero 1989 (37 carillas), el sexto a abril-mayo 1989 (57 carillas), el séptimo a junio-julio 1989 (57 carillas), el octavo al 8 de abril de 1990 (16 carillas); el noveno al 29 de abril de 1990 (16 carillas); el décimo al 27 de mayo de 1990 (16 carillas), y el onceavo número a julio-agosto de 1991 (20 carillas).

9 En el primer número escriben Pedro Susz, como colaborador externo, y miembros del Movimiento: Maria Teresa Flores, Iván Sanjinés, Beatriz Palacios, Marcos Loayza y Gustavo Cardoso. En el segundo vuelve a escribir Susz, y se suman como colaboradores externos Amalia de Gallardo, Julio Peñaloza Bretel, Eduardo Ascarrunz Rodríguez y Jorge Sanjinés. Del Movimiento escriben Rodrigo Ayala, Raquel Romero, Liliana de la Quintana y Diego Torres. En 
demasiado elaborada que a priori se mantenga rígida, sino más bien un diseño que va cobrando forma y complejidad en el propio devenir del proyecto. Compuesta fundamentalmente por textos, aunque hay también fotografías de variados tamaños, en la elección tipográfica de los dos primeros números —con un formato de letra que semeja el de las máquinas de escribir- se percibe aún cierto espíritu artesanal, mientras que a partir del tercero decanta una fisonomía más convencional. En términos visuales, uno de los elementos más interesantes es la presencia de dibujos hechos a mano, viñetas, caricaturas y ocasionalmente alguna tira cómica —entre las que figura "Mafalda" (Quino, Argentina). En efecto, el humor irónico y profundamente crítico que se desprende de las ilustraciones interpelan de modo directo y coloquial al lector convirtiéndolo en cómplice, máxime cuando se están discutiendo problemáticas "serias" del ámbito audiovisual como la crisis económica, la merma de producción en celuloide, la alienación cultural a través de la TV, la crisis del circuito de exhibición frente a la escasez de público, el exceso de violencia en los productos televisivos importados.

La sección principal, con notas que giraban alrededor de un tema de discusión común, se denominó desde el comienzo "Primer plano" y fue la única

el tercer número, uno de los más densos a nivel reflexivo y analítico, la mayoría son colaboradores externos: Fernando Lozada, Erik Torrico, Sandra Aliaga, Carlos Mesa, Alfonso Gumucio Dagron y Oscar García. En el cuarto número escriben como colaboradores externos Raúl Rivadeneira Prada, Nazario Cuenca, Guido Pizarroso, Pedro Susz, Norman Gonzales Pereira (reproducción), Julio de la Vega y Amalia de Gallardo, y miembros del Movimiento Jean Claude Eiffel y Diego Torres. En el quinto número son columnistas externos al Movimiento: Danielle Caillet, Rubén Vargas, Pedro Susz, Armando Urioste y José Ballón. Miembros del Movimiento: Alfredo Ovando y Rodrigo Ayala. En el sexto número escriben sólo los colaboradores externos: Pedro Susz, Julio Peñaloza Bretel, Riberto Gervitz, Jorge Sanjinés, Hugo Kovensky, y se reproduce un texto de Umberto Eco. En el séptimo firman los siguientes colaboradores externos: Ronald Grebe Lopez, Alfonso Gumucio Dagrón, Luis Bredow, Hugo Ara, Agustín Quiroga Arce, Julio de la Vega, Carlos Mendizábal, Luciano Castillo, Pedro García Espinoza, Oscar García, Luis Mérida y se reproduce un cuento de Oscar Soria. Del Movimiento escriben Diego Torres y Marcos Loayza. En el octavo número escriben los asistentes de redacción Nadya Gutierrez Aldayuz y Eduardo Gutierrez, y del Movimiento Liliana de la Quintana y Jean Claude Eiffel. En el noveno número escriben Senel Paz y se reproducen fragmentos de un texto de Jorge Sanjinés, y del Movimiento escribe Diego Torres. En el décimo número nadie del Movimiento escribe, mientras lo hacen Marcela Calderón Durán, Eduardo Rodríguez y Nadya Gutiérrez Aldayuz. En el onceavo número escriben como colaboradores externos Pedro Susz, Antonio Eguino, Waldo Lizon T., se reproduce un texto teórico de Jean Claude Carriere, y del Movimiento escribe Diego Torres. 
CATEDRAL Tomada: Revista de crítica literaria latinoamericana / Journal of Latin American Literary Criticism Pequeña historia de un proyecto utópico: el Movimiento del Nuevo Cine y Video Boliviano y su Revista Imagen

que se mantuvo a lo largo del tiempo. También era habitual otra llamada "Imagen en Movimiento", donde se volcaban noticias internas del Movimiento y anuncios (convocatorias/concursos). Bajo "Imágenes del cine boliviano" e "Imagen Latinoamericana" — nombres que aparecen a partir del segundo número hasta el cuarto-solían encontrarse artículos o columnas breves sobre la vida del campo audiovisual vernáculo y regional respectivamente (festivales, seminarios, y premios). La cartelera, que anunciaba ciclos de cine organizados por el Movimiento o la Cinemateca, siempre estuvo presente; y fueron regulares las reseñas breves respecto de algún video, proyecto o productora-miembro del MNCVB. También fue reiterada la inclusión de entrevistas (producidas por la revista, o reproducidas de otros medios), textos/manifiestos de cineastas/intelectuales reconocidos, notas de homenaje y fichas filmográficas, todo lo cual señalaba - número a número- cierto planteamiento filiatorio o tradición selectiva. ${ }^{10}$ No faltaron la sección de crítica sobre films y ocasionalmente algún libro; el comentario respecto de una institución local ligada al cine, así como tampoco estadísticas, encuestas y rankings. Incluso, de forma original, el primer y segundo número cuentan con un ejercicio lúdico: el "cinegrama", un crucigrama con preguntas sobre cine. Y si en definitiva, de imágenes hablaba la revista, resultaba coherente cerrar cada edición con la reproducción de fotografías o fotogramas de películas.

\footnotetext{
${ }^{10}$ En el primer número hay un texto sobre Buñuel con su respectiva reseña filmográfica, y una entrevista al actor soviético Andrei Rostotski. En el segundo una breve ficha filmográfica sobre Jorge Sanjinés; en el tercero una entrevista a Oscar Soria y un homenaje a Luis Espinal. En el cuarto hay una charla con Antonio Eguino y su reseña filmográfica. En el quinto número hay toda una sección de homenaje a Oscar Soria, recientemente fallecido, con distintos textos y su filmografía; y un breve escrito de homenaje a Amalia de Gallardo - también fallecida. En el sexto número figura una ficha de la película muda Wara Wara (José María Velasco Maidana, 1930), una entrevista a la realizadora suiza Patricia Moraz y una reseña filmográfica de Paolo Agazzi. En el séptimo figura la ficha técnica de La Nación clandestina (Jorge Sanjinés, 1989), una nota sobre Abel Gance y una entrevista realizada a Paul Leduc. En el octavo número hay una entrevista a Jorge Sanjinés, en el noveno una a Pedro Almodóvar y en el decimoprimero a Jorge Vignati.
} 
2. Polémicas furibundas y sintonías programáticas

Con notas y artículos de diferente extensión y por lo general firmados, Imagen funcionó como tribuna de debate público, de crítica y autocrítica desde y hacia los propios videastas y sus producciones. Por ejemplo, el artista visual y videasta Diego Torres advirtió ya en el segundo número sobre el déficit expresivo-creativo de las experiencias de video, demasiado ancladas en el documental testimonial o etnográfico, y demandó a sus colegas dejar de exhibir reiterativamente la miseria local desde una perspectiva esquemática para restituir al lenguaje audiovisual audacia y experimentación, a fin de que el calificativo de "nuevo" no se redujera a una cuestión cronológica. ${ }^{11}$ Torres diagnosticaba una suerte de:

[...] círculo vicioso de las imágenes y los relatos que con escasas variantes reiteran la problemática social y política de nuestras clases explotadas, desde un ángulo demagógico y paternalista [...] creo que a estas alturas ya se debería haber hollado el terreno de la autocrítica y también de la crítica a dirigencias sindicales y políticas, que desde las trincheras de la izquierda hicieron poco menos que entregar en bandeja el país a la derecha. (Torres, Nuevo cine 38)

En consonancia con los objetivos señeros del Movimiento, las grandes preocupaciones tratadas por la revista en la sección "Primer plano" en sus números 1 a 4 son, por un lado, el estado de la producción nacional — sus problemas de exhibición y distribución, la merma de público, la falta de apoyo económico estatal- y la relación con los premios (particularmente el Cóndor de Plata) en tanto estímulo, incentivo y sostén económico-institucional. Por otro

${ }^{11}$ Algo semejante había notado María Teresa Flores: "La cuestión radica, en que si bien, se realizan temas de carácter social y político, dando como resultado generalmente documentales, estos caen en la descripción, ocasionando que los resultados sean de carácter coyuntural y no tengan la viva fuerza que merecen" (Flores 10) 
CATEDRAL TOMADA: Revista de crítica literaria latinoamericana / Journal of Latin American Literary Criticism Pequeña historia de un proyecto utópico: el Movimiento del Nuevo Cine y Video Boliviano y su Revista Imagen

lado, pero relacionado estrechamente con lo antedicho, la otra inquietud gravitaba en torno de la ausencia de legislación para cine y el deficitario reglamento general del servicio televisivo. La revista procuró garantizar el abordaje de los temas desde distintas escalas (global, regional y local) y ángulos (teórico, político, económico, cultural, histórico y legal), insertando al audiovisual en un sistema comunicacional más amplio no aislado de su contexto; y apeló a colaboradores externos cuya idoneidad y prestigio dieran consistencia no sólo a la reflexión sino también a la misma publicación. De la lectura de estos números se desprende que el objetivo era ofrecer elementos de análisis para la comprensión de los problemas, y argumentos sólidos para la discusión en la esfera pública. Esta voluntad de análisis pormenorizado evidenciaba: primero, la zozobra crítica respecto del espacio audiovisual local al que era urgente describir con precisión y diagnosticar sus fortalezas y falencias; segundo, la necesidad de denuncia pública respecto del desorden imperante; y tercero, la decisión de trazar y comunicar alternativas sustentables y consensuadas que permitieran reorganizar el sistema y fortalecer los emprendimientos locales, independientes y sin fines de lucro comercial. En el editorial del $\mathrm{N}^{\mathrm{o}} 3$ se lee:

La ausencia de una política comunicacional coherente, que siente las bases para la utilización del medio televisivo como un servicio a la comunidad y no como una gigantesca empresa comercial, es una contribución más a que "el caos televisivo" convierta al espectador en una presa fácil de alienación y consumo [...] se añade, la falta de leyes u otros instrumentos legales que permitan establecer mecanismos de interacción más o menos justos entre productores, gerentes, técnicos [...] Lo que proponemos los productores independientes es dotar al país y a la población de un instrumento comunicacional, como la televisión, que refleje las necesidades y los intereses de las mayorías nacionales. (Imagen, Editorial III 1) 
El peso y la influencia de la TV en el ámbito local se problematizaron extensamente en los números 3 y 4, en cuyas portadas la imagen del aparato es protagónica. Para su tratamiento, además de artículos profundos que revisan y polemizan sobre la precaria reglamentación vigente desde mayo de 1986, la revista elaboró un cuestionario recabando las opiniones de los responsables de algunos de los canales más importantes de La Paz permitiendo a los miembros del sector y lectores en general, comparar y contrastar las perspectivas. ${ }^{12}$ Todos coincidían en la vaguedad del reglamento, su carácter incompleto e insuficiente en relación al fomento de la producción nacional, además de ratificar la coherencia del plan político económico de corte neoliberal del presidente de turno (Víctor Paz Estenssoro) que desnacionalizaba industrias y privatizaba el espacio audiovisual. ${ }^{13}$ Justamente, para "encender" las páginas de discusión y poner (más aún) al descubierto el posicionamiento del gobierno, Imagen incluyó también la voz oficial: esto es, las auspiciosas declaraciones que en junio de 1986 hizo a “Antena” (Publicación de Escuelas Radiofónicas de Bolivia) Andrés Petricevich -Ministro de Transporte y Comunicaciones- a propósito del reglamento de TV del cual fue responsable. ${ }^{14}$ Pero mientras éste argumentaba que no había recibido

${ }^{12}$ Cabe recordar que el monopolio televisivo estatal se fractura en 1985. Hasta ese momento la TV boliviana contaba con ocho canales universitarios (uno por departamento menos en Pando), y uno central nacional (Canal 7) con sede en La Paz y cobertura a las ciudades capitales de ocho departamentos, además de centros mineros. Luego de la incorporación del sistema privado, el total de canales en todo el país asciende a treinta y cuatro (Mesa La comunicación social).

${ }^{13}$ Tal como explicara Fernando Lozada: “[...] el Reglamento en cuestión está limitado por su carácter asistemático y ambiguo, por su índole exclusivamente técnica, despojado de toda perspectiva social, comunicacional y política, plagado de retórica en los puntos que exigen normas precisas ya aplicables. En suma, no es el instrumento ideal para orientar la comunicación como factor de desarrollo y cambio en la construcción histórica de la nación, y menos para la democratización global de la sociedad" (Lozada 6).

${ }^{14}$ Según el ministro, se trataba de un muy buen marco legal, elaborado con detenimiento por expertos internacionales — de los cuales elude dar información-: "El gobierno gobierna y emite sus reglamentos y decretos sin consultar, porque esa es su función [...] Queremos que el público tenga acceso a la mayor información posible de manera que escuche las diferentes tendencias que dan a través de los medios de comunicación [...] no se ha querido tocar el aspecto de la programación para no dañar la libertad de prensa. Esperamos que los canales sepan usar la libertad que tienen" (Petricevich 12-13). El subrayado es nuestro. Véase, en contraste, el planteo de Eiffel en el mismo número: "[...] cotidianamente se ofrece al teleespectador un sinfín de programas principalmente dirigidos a distraer en el peor sentido del término, estimulando y creando expectativas y necesidades falsas que al final legalizan aun mas una situación de dependencia política y económica [...] el contenido de la mayoría de los programas, en el fondo, 
CATEDRAL Tomada: Revista de crítica literaria latinoamericana / Journal of Latin American Literary Criticism Pequeña historia de un proyecto utópico: el Movimiento del Nuevo Cine y Video Boliviano y su Revista Imagen

planteos orgánicos de reforma por parte de entidad alguna, Imagen divulgó dos artículos en los que se señalaba el esfuerzo mancomunado que diferentes instituciones —incluída el Movimiento-, poco después de la emisión del reglamento, encararon para escribir una nueva propuesta. Ésta planteaba: "sentar las bases para una televisión que cumpla su fin social, que satisfaga las expectativas nacionales mediante mensajes que consoliden la identidad del hombre boliviano [...] el respeto a la idiosincrasia y sensibilidad del hombre boliviano a fin de evitar su alienación” (Pizarroso 16-17).

Número a número, la revista alertó sobre el desequilibrio y despersonalización que provocarían los productos extranjeros, ${ }^{15}$ y sugirió medidas concretas para la protección del sector, tales como: la creación de un fondo de fomento para la producción nacional; la implementación a nivel curricular de formación de pensamiento crítico frente al consumo audiovisual, y la democratización del servicio, incluyendo la participación de organizaciones sociales en la definición de la programación de los contenidos. Y es que: "Mientras sigamos en este camino la alienación estará a la orden del día. Nuestros canales seguirán vomitando imágenes ajenas y no sería de extrañarse que nuestros jóvenes del futuro sean tan "ajenos" como ellos a nuestra realidad, a nuestra necesidad y a nuestra autoafirmación como pueblos" (MNCVB, Video y producción 26). Desde un posicionamiento progresista, nacional y popular, Imagen aseveraba:

La televisión es sobre todo un servicio público, hecho que no puede ser omitido por ninguna reglamentación en este campo. Por su carácter educativo, la televisión debe responder a las necesidades del país, a la

es el mismo [...] solo son pensados en función de generar ingresos económicos para los canales [...] quienes definen las políticas y orientaciones de los canales son las fuentes de financiamiento, principalmente empresas publicitarias. Así es posible expresar aquellos valores que, en amplia mayoría, EE.UU. aspira extender al resto del mundo, lo cual a la larga, significa que esta producción tiende a una gradual destrucción de nuestras culturas e identidades" (Eiffel 18-19).

${ }^{15}$ El porcentaje de contenidos televisivos de origen extranjero era de alrededor del $70 \%$. 
CATEDRAL TOMADA: Revista literaria latinoamericana / Journal of Latin American Literary Criticism María Gabriela Aimaretti

formación de hombres capaces de enfrentar el desarrollo. Una política sectorial de televisión, que debe formar parte de una política global de comunicación, no puede ignorarlo. Postergar negligentemente la elaboración de una política global de comunicación, que hoy es urgente, es hacerse cómplices de los agentes que perpetúan el atraso y la dependencia. (Imagen, Editorial IV 1)

La perspectiva política que se desprende de los fragmentos expuestos está en estrecha sintonía con aquella que, paralelamente, cineastas y videastas latinoamericanos ligados al tercermundismo y el regionalismo cultivaban, entre quienes se destaca Octavio Getino. De ahí que la revista procurase, desde su primera edición, amplificar la mirada hacia las prácticas audiovisuales del Cono Sur y sus redes de trabajo divulgando, por ejemplo, el quehacer de la Fundación del Nuevo Cine Latinoamericano, sus realizadores y ese gran proyecto educativo inspirador para el Movimiento como fue la Escuela de Cine y TV de San Antonio de los Baños que brindaba "la oportunidad de contar con profesionales capaces de oponer a la alienante invasión audiovisual del Norte, producciones que nos pertenezcan y reflejen nuestra realidad" (Imagen, Editorial II 1). ${ }^{16}$

\footnotetext{
${ }^{16}$ Respecto del espíritu latinoamericanista que animaba la publicación, no debe olvidarse que una de las miembros del Movimiento, Beatriz Palacios — compañera de Jorge Sanjinés-, era también parte del Comité de Cineastas de América Latina. Reseñemos notas de corte latinoamericanista: en el primer número se escribe sobre Miguel Littín; en el segundo se comenta en extenso la VIII edición del Festival Internacional del Nuevo Cine Latinoamericano y se reproduce el discurso que Gabriel García Márquez - presidente de la Fundación del Nuevo Cine Latinoamericanodiera al inaugurar la nueva sede de la Fundación y la Escuela Internacional de Cine y TV de San Antonio de los Baños. En efecto cabe señalar que en el tercer número de la Revista (marzo-abril 1987) Loayza deja el comité editorial porque viaja a Cuba becado para estudiar en la escuela de la Fundación. En el tercer número se reproduce una nota de Glauber Rocha en torno del Cinema Novo y una reseña de su filmografía, mientras que en el cuarto número hay un extenso artículo sobre el cine argentino contemporáneo. En el quinto número aparece una nota sobre el proyecto de serie latinoamericana de TV "Visión Latina", nacido en el Festival de La Habana en 1988. En el sexto hay varios artículos sobre el Movimiento de Videastas Latinoamericano. En el séptimo figura una nota sobre cine cubano. En los números 8, 9, 10 y 11 no se consignan noticias sobre el ámbito latinoamericano.
} 
CATEDRAL Tomada: Revista de crítica literaria latinoamericana / Journal of Latin American Literary Criticism Pequeña historia de un proyecto utópico: el Movimiento del Nuevo Cine y Video Boliviano y su Revista Imagen

\section{Papeles en devenir}

Más arriba mencionábamos el ritmo variable de la publicación y también los cambios en su personal interno. Nótese que ya entre el tercer y cuarto número hay una diferencia de varios meses: entre abril y septiembre de 1987 la revista no logra continuar con su periodicidad pero sobre esta "pausa" no se hace mención alguna. En ese cuarto número mientras Iván Sanjinés sale del comité editorial — hasta allí exclusivamente masculino- se suman dos mujeres: María Teresa Flores —colaboradora regular- y Liliana De la Quintana —quien, simultáneamente, cumplía dentro del Comité Ejecutivo del Movimiento el rol de Secretaria de Difusión y Cultura. ${ }^{17}$ Respecto de la participación de las mujeres en Imagen nótese que aunque en los testimonios recogidos ninguna videasta expresó que fueran discriminadas a la hora de escribir y divulgar sus reflexiones, la mayoría de las notas fueron firmadas por hombres. ${ }^{18}$

Entre octubre de 1987 y diciembre de 1988 el Movimiento no consigue publicar ningún número; mas cuando lo hace y sale el quinto, se observan dos cambios significativos: uno tiene que ver con la estructura del comité editorial; el otro con el formato. Si bien la dirección continúa a cargo de Eiffel, aparecen una serie delimitada de créditos en los roles de: jefe de redacción, María Eugenia Muñoz; diseño de arte, Marcos Loayza; responsable de publicidad, María Teresa Flores; y Rodrigo Ayala, responsable económico. ${ }^{19}$ En relación al formato,

${ }^{17}$ Patricia Quintanilla ocupaba la tesorería y Raquel Romero el rol de secretaria ejecutiva: de ese modo eran tres las mujeres dentro del CE del Movimiento, un número significativo.

18 En el primer número escriben dos mujeres (Maria Teresa Flores y Beatriz Palacios), en el segundo tres (Amalia de Gallardo, Raquel Romero y Liliana de la Quintana) mientras que figura en una sección especial una imagen de la fotógrafa y videasta Danielle Caillet. En el $n^{\circ} 3$ sólo escribe Sandra Aliaga y en el cuatro Norman Gonzales y Amalia de Gallardo. En los siguientes números las colaboraciones femeninas son aún más escasas.

${ }^{19}$ En los números 6 y 7 se mantiene el mismo equipo editorial y aunque en los créditos se apunta a Beatriz Palacios como colaboradora, no hay ninguna nota firmada por ella u otra mujer. Figuran, también en créditos, como corresponsales femeninas: Jenny Ampuero, por el departamento de Santa Cruz, y Katia Uriona por Cochabamba. En el número 7 Ampuero firma una entrevista con el director de SAFIPRO (Santa Cruz Films Producciones), Enrique Alfonso en la que se da a conocer el trabajo de la productora de miniseries televisivas. En el número 8 Teresa Flores y Beatriz Palacios ya no figuran en los créditos de la publicación, pero se suman como asistentes 
aunque la tapa sigue siendo a color e impresa en papel fotográfico, se trata de un tamaño más grande - carta-, con un diseño más acabado, donde las fotos y los avisos publicitarios cobran relevancia, se utiliza el foto-montaje, collage y los dibujos a mano presentan mayor elaboración y atractivo. La organización de las secciones también se modifica: no obstante continúan las líneas temáticas previas -cine local, cine latinoamericano, avisos, concursos, informaciones- cambian sus designaciones a etiquetas generales y convencionales - "Homenaje", "Concursos", "Varios"- y sólo permanece "Primer Plano". Después del silencio de casi un año, el editorial advierte:

Continuar con la publicación de una revista que tenga las características de IMAGEN en nuestro medio, es tarea ardua y lleva consigo problemas que tardan mucho tiempo en superarse. Varios meses después de ser publicado el último número, salimos nuevamente a circulación con nuevas perspectivas y con cambios que se irán notando gradualmente en las próximas ediciones. Queremos convertir a IMAGEN en una publicación más amplia, que llegue a un público más numeroso y que sea leída en todo el país. Esperamos convertirnos en instrumento práctico de difusión con contenidos que sirvan tanto a estudiantes, como a todos aquellos quienes se interesan por lo que sucede en materia audiovisual en Bolivia y el resto del mundo, y tienen deseos, no sólo de informarse, sino también de conocer más en estas áreas. (Imagen, Editorial V1)

Aunque consideramos que la motivación general de la revista no cambia sustancialmente, sí se percibe que poco a poco hay menor énfasis político: la reivindicación del audiovisual dentro de las luchas nacionales recuperando la

de redacción: Susana Cabezas y Nadya Gutiérrez Alcayuz — quien en ese número hace una crítica al film de Sanjinés La nación..., en el siguiente una crítica a un film comercial brasileño, y en el $\mathrm{N}^{\mathrm{o}} 10$ una critica a un film comercial norteamericano. Esa formación continúa en los $\mathrm{N}^{\circ} 9$ y 10. En el $N^{\circ} 11$ Muñoz ya no está al frente de la redacción: Eiffel sigue como director, y el consejo editorial vuelve a ser enteramente masculino (Diego Torres, Marcos Loayza y Fernando Prado). No figuran colaboradores ni corresponsales. 
CATEDRAL Tomada: Revista de crítica literaria latinoamericana / Journal of Latin American Literary Criticism Pequeña historia de un proyecto utópico: el Movimiento del Nuevo Cine y Video Boliviano y su Revista Imagen

realidad del país o de sus mayorías, irá perdiendo pregnancia en los textos. Sin embargo, también es destacable que de la mano del nuevo diseño de roles y responsabilidades —más diverso y equitativo en términos de género-, la sección "Primer plano" del No 5 esté dedicada a un "tema siempre desplazado": la relación "imagen-mujer”. Presentando a las tres realizadoras que en ese número reflexionan sobre el peso específico de la mirada femenina dentro de la praxis del video boliviano —-Danielle Caillet, María Eugenia Muñoz y Raquel Romero-, el editorial las pondera como: "Puntos de vista que, creemos, deben convertirse en tema de discusión por la imperiosa necesidad que tenemos para que la mujer acceda de una manera permanente a la producción y realización audiovisual en nuestro país" (Ídem). Nótese, sin embargo, que en los siguientes números no aparecerán textos de la originalidad y autorreflexividad como los que se presentan en esta edición. ${ }^{20}$

Otra de las notas relevantes en el número 5, y que mantiene el espíritu latinoamericanista de la revista, corresponde a la trascripción del "Documento final", síntesis del trabajo de evaluación, diagnóstico y propuesta que videastas del Cono Sur realizaron en el "Seminario de Experiencias de Video en América Latina" que tuvo lugar en Quito en octubre de 1988. En efecto, se trata de un material que da cuenta de la inscripción del MNCVB en una red más amplia a nivel regional, en pleno proceso de conformación y coordinación. ${ }^{21}$

El sexto número sale con retraso, y corresponde a los meses de abril-mayo de 1989. En los créditos se advierten dos elementos a destacar. Por un lado, la presencia de patrocinios muy significativos como son el de la Cinemateca Boliviana y el del Grupo Ukamau: auspicios que se tradujeron en un respaldo institucional $\mathrm{y}$, aunque nadie lo recordara en las entrevistas, seguramente económico. Por otro lado, se nota un crecimiento exponencial de colaboradores,

${ }^{20}$ Para detenerse en los textos de las videastas, ver Aimaretti (2017).

21 Llamativamente, las filmografías apuntadas en este número corresponden a cineastas no bolivianos ni latinoamericanos: después de una nota sobre los italoamericanos en Hollywood, se reseña la producción de Sergio Leone, Francis Ford Coppola, Michael Cimino, Brian De Palma y Martin Scorsese. 
tanto paceños, como de otros departamentos y de países latinoamericanos, llegando a casi veinte integrantes, lo que expresa la voluntad por romper el cerco de la ciudad y abrirse a la participación de otros integrantes del espacio audiovisual boliviano y del Movimiento, no residentes en La Paz. ${ }^{22}$ En efecto, en varias entrevistas distintos videastas manifestaron que una de las contradicciones más problemáticas puertas adentro del Movimiento tenía que ver con el centralismo paceño, el cual generaba tensiones e incomodidades en los demás departamentos. Incluso, en tren de amplificar el diálogo y generar un ámbito de interlocución plural, a las secciones planteadas en el número anterior se agrega "Carta de los lectores": “[...] porque estamos seguros que los puntos de vista de todos ustedes nos serán de mucha utilidad con el fin de mejorar cada número y ofrecerles un panorama lo más completo posible del acontecer audiovisual boliviano, e información latinoamericana y mundial que pueda servir para incrementar nuestro conocimiento de la imagen en movimiento" (Imagen, Cartas $3)$.

En el editorial del sexto número se anuncia que la presente edición procura pensar las continuidades y rupturas entre el cine latinoamericano producido en los ‘60 y '70 (Nuevo Cine Latinoamericano) y el producido en los '80: revisar el derrotero creativo y discursivo de la nueva generación observando sus aciertos, aprendizajes y necesidades, logros técnicos y deficiencias, las adhesiones y rechazos que despierta en el público, "conscientes que existe el enorme riesgo de caer en un esteticismo intrascendente que acaba en ser "arte por arte", o en tener productos que pasan desapercibidos en el mar de imágenes que vemos cada día, con lo que desperdiciamos enormes esfuerzos que bien pudieran ser empleados en otras realizaciones" (Imagen, Editorial VI 1).

Para tal cometido se dan cita dos provocadores artículos de balance sobre el video boliviano escritos por críticos y comunicadores sociales locales. Pedro Susz, por ejemplo, ubica el fenómeno en un contexto global y señala el

${ }^{22}$ Colaboradores de: Santa Cruz de la Sierra, Cochabamba, Tarija, Oruro, Brasil, Cuba, Chile, Ecuador, El Salvador y Perú. Luego se sumará un colaborador por Uruguay. 
CATEDRAL Tomada: Revista de crítica literaria latinoamericana / Journal of Latin American Literary Criticism Pequeña historia de un proyecto utópico: el Movimiento del Nuevo Cine y Video Boliviano y su Revista Imagen

preocupante aislamiento de los productores vernáculos respecto de las corrientes creadoras más inquietas del cine mundial, a la vez que advierte cierta soberbia y desconocimiento de la propia tradición cinematográfica: "Se cree saberlo todo, o se supone que "la realidad social" transformada en tópico, actuará milagrosamente para cubrir cualquier laguna" (Susz, Sero o no ser 7). Más allá de indicar la escasa producción ficcional, insiste en cierta actitud oportunista en algunas producciones documentales que no siempre se han empapado en profundidad de la compleja realidad registrada.

Luego aparece la voz audaz y autorreflexiva de los jóvenes teleastas y productores cubanos que hacen una evaluación de su experiencia en el medio falencias, desafíos, paradojas y anhelos-; y una nota que ofrece un panorama general del caso brasileño en materia comunicacional (cine, video y televisión) que, aunque problematiza el poderío monopólico de la Red Globo y avanza en describir el cine local, profundiza poco en la producción videográfica de la nueva generación. Cierra "Primer Plano" un extenso artículo teórico de Jorge Sanjinés — "El plano secuencia integral". ${ }^{23}$ Resulta llamativo que la palabra autocrítica y propositiva propiamente dicha de los productores audiovisuales latinoamericanos figure acotadamente en la sección principal, y que los textos que la completan se encuentren en otra parte del número. Es en la sección "Varios" donde aparecen dos contribuciones relevantes. La primera es la convocatoria al próximo encuentro latinoamericano de videastas a realizarse en junio de 1989 en Cochabamba, Bolivia, donde se repasan los antecedentes y justificación, el

${ }^{23}$ Tanto el texto sobre Brasil — escrito por Roberto Gervitz-, como el de Susz son de tenor crítico. Huelga decir que, en el mismo número, en la sección "Varios" pero intercalado con notas que responden a "Primer Plano", figura un breve ensayo de Umberto Eco titulado "La demolición y el insulto" donde se distingue la diatriba y etiquetación; del acto crítico-reflexivo. Es evidente que la inclusión de este texto - antecedido por una presentación del pensador italiano que dice: Humberto Eco tiene 57 años, nació en Piamonte y tiene un sentido del humor del carajo- señala el tono desde el que se pronuncia Imagen y a partir del cual solicita la opinión de sus columnistas. También vale la pena subrayar el carácter autocrítico y autoparódico de los dibujos y caricaturas presentes en el número, tal como el que cierra la edición $\mathrm{N}^{\circ} 6$ acompañado de la siguiente leyenda: "Aclaración: de la serie dedicada a personalidades de nuestro quehacer cinematográfico y videeystico (sic) (solicitada a nuestra redacción) empezamos con los ofideos y los de sangre fría y los saurios y los batracios (lagartos, sapos, vivoras y tortugas). HOY: lagarto serie ABI cineasta de scalafon (sic) \# 1". 
sentido y los objetivos, los temas y la metodología de la reunión: “[...] no debemos satisfacernos con logros particulares y aislados. Compartir, unir esfuerzos, en (sic) el camino que debemos abrir para responder a los efectos nocivos de las transnacionales de comunicación [...] contribuir a la organización del video latinoamericano y analizar el impacto y la eficacia del mundo como instrumento para la Comunicación Popular" (MNCVB, Encuentro latinoamericano 40-41). El segundo, es la trascripción del resumen del Encuentro de Realizadores de Video en el marco del X Festival Internacional del Nuevo Cine Latinoamericano en diciembre de 1988, que puntualiza desafíos, conquistas y dificultades de articulación entre realizadores y entidades a nivel continental en las áreas de gestión/organización, producción, distribución y capacitación; y recoge recomendaciones emanadas del "Seminario sobre Nuevas Tecnologías de la Comunicación Audiovisual en el umbral del siglo XXI".

Complementando el impulso formativo en términos teórico-prácticos, una novedad para la publicación es la inclusión de un recurso didáctico y técnico: un texto de enseñanza utilizado en la Escuela Internacional de Cine y TV de San Antonio de los Baños sobre la dirección de fotografía y su equipo de trabajo. En la misma dirección Imagen divulga una larga y actualizada bibliografía sobre cine, video y comunicación social producida en América Latina.

El número siguiente, el 7, aparece puntualmente: corresponde al bimestre junio-julio de 1989, meses importantes para el video latinoamericano al desarrollarse el encuentro continental en suelo boliviano anunciado en el número anterior. Ello motiva la reflexión sobre el estado actual de los vínculos entre los productores audiovisuales locales, los recelos y disputas que atraviesan el medio, su diversidad y riqueza de perspectivas, recomendando y anhelando el respeto y la concordia, en un escenario que, por elevación, se supone tenso:

[...] debemos partir del respeto que cada uno de los que hacemos video, tenemos que tener por el trabajo de aquel que, honestamente, desde su propia perspectiva, refleja una visión de su entorno; de aquel que utiliza 
CATEDRAL Tomada: Revista de crítica literaria latinoamericana / Journal of Latin American Literary Criticism Pequeña historia de un proyecto utópico: el Movimiento del Nuevo Cine y Video Boliviano y su Revista Imagen

otro lenguaje, diferente al que usamos, para decirnos algo [...] estamos convencidos que podremos hablar de video realmente boliviano, cuando éste se produzca a partir de una unidad que es imprescindible crear entre los realizadores nacionales. Unidad sin mezquindades; sin creer que uno tiene más derecho que otro porque ha producido más; sin trabar la producción de quienes acceden por primera vez al medio; o defendiendo a ultranza el regionalismo [...]. (Imagen, Editorial VII 1) $)^{24}$

La sección principal aborda el campo general en el que se inscribe la producción videográfica: el de las comunicaciones, las nuevas tecnologías y sus políticas de desarrollo. Contemplando los cruces de lo nacional y lo transnacional, y las diferencias e interacciones conflictivas entre países "dependientes y centrales", aparecen una serie de notas que piensan las posibilidades y limitaciones de los medios y sus mediaciones, las fantasías y realidades de los alcances de formatos como el video y su efectiva potencia democratizadora. Los columnistas preservan una actitud crítica y desfetichizadora de las nuevas tecnologías y sitúan sus prácticas y legislaciones en un marco más amplio: el de las relaciones económicas y de poder. Es decir:

En términos de impacto cultural, la brecha tecnológica se asemeja a un hachazo en la costura del proceso de interacción cultural. Los términos de intercambio entre culturas son cada vez más desigual (sic). Las nuevas tecnologías son una nueva forma de prepotencia para imponer el rigor de las necesidades de expansión de mercados para los productos de los países industrializados. Dicha expansión se facilita a través de un

\footnotetext{
${ }^{24}$ Resulta sintomático que en el campo de la crítica y análisis, también se adviertan tensiones, que la Revista recoje y da un lugar en el número: en efecto, en la sección previamente inaugurada de "Cartas" se levanta una polémica entablada por correspondencia entre dos colaboradores de Imagen, Pedro Susz y Mauricio Souza, donde se cuestionan mutuamente los métodos y formas del análisis sobre el campo audiovisual local contemporáneo, y de alguna manera se disputan autoridad, aduciendo legitimidad por trayectoria el primero, y por audacia el segundo. Veinticinco años después, Souza será el apasionado editor de la obra crítica completa de Susz publicada por Plural en 2015 en cuatro importantes volúmenes.
} 
CATEDRAL TOMADA: Revista literaria latinoamericana / Journal of Latin American Literary Criticism María Gabriela Aimaretti

proceso de homogenización cultural y se entorpece en la medida en que subsiste una pluralidad cultural. (Gumucio Dagron, Juguete 8)

No obstante, en la sección también se señala la existencia de usos alternativos de las tecnologías de información y comunicación en y para América Latina tendientes a acciones de resistencia, en paralelo al desarrollo de una conciencia crítica en los espectadores. Asimismo se problematizan la transferencia de medios a comunidades indígenas, las experiencias de televisión en el agro boliviano por y para quechuas y aymaras (como el caso de la productora cochabambina Tarpuy), y los cruces entre prácticas videográficas y antropológicas. Incluso uno de los artículos comenta sobre la utilización del video como un medio evangelizador y catequístico, lo cual señala la apertura y diversidad de puntos de vista que acoge la publicación, que en este número incluye además referencias de experiencias radicadas en Santa Cruz, departamento del cual no se habían divulgado noticias previamente.

Desde un ángulo de análisis distinto, "Primer Plano" cierra con un artículo que pone el foco en el vínculo entre audiovisual y literatura, texto que a su vez dialoga con otro que tematiza las relaciones entre erotismo, cine y literatura (de la sección "Varios) y con la publicación de un cuento inédito de Oscar Soria (sección "Cultura”) con la intención de: “[...] crear un espacio de relación entre la literatura y la imagen en movimiento [...] rescatar del olvido textos escritos por las grandes figuras de nuestro cine que [...] ya no están entre nosotros" (Imagen, Los que nunca 34). ${ }^{25}$

Como en la edición anterior se socializa un nuevo aporte técnico con la trascripción de un texto de enseñanza utilizado por la Escuela de San Antonio de los Baños, esta vez referido a la dirección de arte. También se hacen semblanzas de productoras o instituciones de video latinoamericano que, aunque breves, permiten un conocimiento de los participantes que se harán presentes en el

25 En tren de continuar la reflexión en torno de las relaciones entre distintas series artísticas, aparece una nota breve que refiere a las interacciones entre música y video boliviano, los problemas y las tareas de composición de banda sonora. 
CATEDRAL Tomada: Revista de crítica literaria latinoamericana / Journal of Latin American Literary Criticism Pequeña historia de un proyecto utópico: el Movimiento del Nuevo Cine y Video Boliviano y su Revista Imagen

Encuentro de Cochabamba. Por último, en este número se destaca un texto que recuerda la tarea del Taller de Cine de la UMSA: justamente, la columna se ubica en la sección "Homenaje", en general asociada a personalidades de relevancia para el medio, ya fallecidas. La semblanza del Taller se halla envuelta en la amargura de constatar que, por desidia estatal, un proyecto necesario - ya que implica un espacio institucional de formación audiovisual- se va apagando al no contar con el debido apoyo. ${ }^{26}$

Casi un año después, ve la luz Imagen $\mathrm{N}^{\circ}$ 8: no pudiéndose sostener económicamente el diseño anterior, se optó por un acuerdo con el periódico "Presencia" y salir los días domingos junto al matutino. Así lo hace el 8 de abril de 1990: aunque más pequeña, breve e impresa en papel de diario, con menos fotografías y dibujos, sin las tradicionales secciones ni auspicios comerciales, Imagen vuelve a salir en busca de sus lectores. Hay pocos cambios en el equipo de trabajo: María Teresa Flores deja su rol en la publicidad; y se suman como asistentes de redacción Nadya Gutiérrez Aldayuz, Susana Cabezas y Eduardo Rodríguez, y como corresponsal de Uruguay, Hernán Dinamarca, uno de los pensadores más lúcidos sobre el video latinoamericano del período. A los patrocinios de la Cinemateca Boliviana y el Grupo Ukamau, se añade el de la Secretaría de Comunicación de la Conferencia Episcopal de Bolivia, incorporación obvia pues "Presencia" era un diario dependiente de la institución que nucleaba a los obispos católicos locales. Dice el editorial del $\mathrm{N}^{\circ} 8$ :

[...] no podemos ceder a la tentación de olvidar todo lo hecho a lo largo de siete números de publicación durante los últimos dos años (sic). Creemos firmemente que el espacio dedicado a la discusión de los temas

\footnotetext{
${ }^{26}$ El Taller de cine funcionó desde 1979 hasta el golpe de Estado de García Meza en 1980. Todos los materiales - editados y en bruto- y buena parte de los insumos fueron destruidos y saqueados. Diego Torres (1989) señala que tras el retorno democrático la reactivación del Taller fue muy difícil debido a la mengua progresiva del presupuesto universitario, lo que redundó en la ausencia de inversión en infraestructura y equipamiento (las máquinas en super 8 usadas en 1979, ya resultaban inútiles). Con todo, y pese a todo, Torres reseña una nómina de trabajos colectivos finales de alumnos, subrayando que el taller continuó como espacio de formación hasta el final de la década.
} 
referidos a la imagen en movimiento debe crecer y convertirse en referencia permanente para todo aquel interesado en este campo, más allá de la simple distracción [...] "volvemos a la carga" en busca de una legislación adecuada para nuestro cine y video [...] queremos compartir con ustedes nuestras preocupaciones y hacerlos partícipes del despegue de la imagen boliviana. (Imagen, Editorial VIII 3)

El momento de "despegue" de la imagen boliviana al que se refiere tiene que ver con dos situaciones puntuales: el exitoso estreno del film de Jorge Sanjinés y el Grupo Ukamau, La nación clandestina (1989), y la reactivación de la demanda por una Ley Nacional de Cine. ${ }^{27}$ En efecto, el grueso del número está dedicado a comentar y ponderar el film mencionado y la parte central la ocupa una entrevista a Jorge Sanjinés, quien hacia el final de la misma advierte: “[... ] no estoy tan preocupado por nosotros como lo estoy por los jóvenes que ya están maduros para hacer cine en nuestro país y que no tienen cómo financiar una película -con rara excepción- y que si no se crea pronto una instancia financiera se van a frustrar y esto es grave culturalmente para el país. Creo que esa nueva generación tiene cosas importantes que decirnos" (Sanjinés en Eiffel, Charla 11).

En esta edición no hay ninguna columna sobre video latinoamericano o las acciones concretas del MNCVB, sino apenas la referencia de un taller de sonido para mujeres del Movimiento. Por contraste, se incluye una nota sobre la última premiación de los Óscar norteamericanos y la presencia, en distintos lugares de la revista, de imágenes ligadas a la cultura de masas norteamericana - como el retrato intervenido de Marilyn Monroe por Andy Warhol, un fotomontaje del perfil de Alfred Hitchcock y una imagen de Woody Allen junto a Mia Farrow. Una referencia y repertorio iconográfico ciertamente impensables en los primeros

${ }^{27}$ De hecho en una carilla de la revista se insertan fragmentos muy breves del Proyecto Ley y palabras alusivas a la necesidad de militar a favor del cine vernáculo recogidas de la voz de Luis Espinal. 
CATEDRAL TOMADA: Revista de crítica literaria latinoamericana / Journal of Latin American Literary Criticism Pequeña historia de un proyecto utópico: el Movimiento del Nuevo Cine y Video Boliviano y su Revista Imagen

números, pero que podrían deberse al control "relativo" del diseño de la revista, al salir ésta como suplemento de "Presencia". ${ }^{28}$

Unas semanas después, Imagen llega a su novena edición el 29 de abril 1990. La organización se mantiene pero la mayoría de las imágenes incluidas responden a films extranjeros e íconos hollywoodenses. El tema del editorial se enfoca en una preocupación histórica para el Movimiento como es la concreción de la Ley de Cine, de ahí la interpelación enérgica a todos los miembros del sector para conseguirla:

No podemos dejar pasar esta situación porque somos los nuevos realizadores quienes podremos beneficiarnos en mayor medida de las disposiciones de la Ley. Creemos firmemente que ahora es el momento en que una acción decidida y conjunta de TODOS los que tenemos que ver con la imagen en movimiento y con la cultura en general, debe ponerse en marcha dejando de lado esa indiferencia que durante tanto tiempo ha mantenido en la simple queja aquello que de manera coordinada pudo ser realidad tiempo atrás. (Imagen Editorial IX 3)

En tren de darle sustancia y amplitud pública a la discusión, se divulga el resumen de un texto que Jorge Sanjinés había escrito al respecto, en el cual sugería la creación de un fondo de fomento rotativo y el estímulo a un cine de calidad artística antes que comercial. Según su perspectiva — tal vez demasiado confiada en los espectadores bolivianos-: "El público interno del cine nacional es un público ávido de su propia imagen [...] la propia crisis lo impulsa al proceso de autocontemplación y reflexión colectiva" (Sanjinés, Una nueva 5).

La otra nota importante del número abreva en las proyecciones del cine mundial tomando como referencia autores del cine norteamericano, alemán e italiano, recomendando:

${ }^{28}$ Nótese además que en los números 8 y 9, la leyenda que acompaña el nombre de la revista y figura en la portada cambia: de "La Revista boliviana de cine y video" pasa a "...cine, video y T.V'. 
Es imprescindible salir de una óptica cerrada, insistiendo en modelos estéticos y expresivos anacrónicos. Debemos superar las fronteras domésticas, derribar nuestros propios muros, para que la producción nacional pueda alcanzar una dirección que le permita acceder a los principales centros culturales del mundo, no como exotismo ni como muestra del subdesarrollo sino con un nivel de creatividad y calidad respetables en cualquier contexto cultural. (Torres, Cine de 19)

Tras algunos "flashes informativos", e intercalado entre reseñas de trabajos locales y dos críticas a films comerciales extranjeros, encontramos una única mención a la actividad de videastas latinoamericanos con el anuncio del Encuentro Latinoamericano de Video en Montevideo 1990: se trata de información general, con datos operativos, que no se asemeja a la descripción detallada que se hiciera con motivo del encuentro en Cochabamba en el número 6 de Imagen. Respecto del Movimiento, hay sólo una noticia breve en la contratapa - compartiendo el espacio con los anuncios publicitarios- donde se convoca a la inscripción de nuevos miembros de cara a la fecha de renovación de su comisión directiva.

Un mes más tarde, el domingo 27 de mayo de 1990 sale el décimo número: no obstante el staff se mantiene, por primera vez desde 1986 la revista no tiene editorial escrito, lo cual podría leerse como síntoma de crisis interna en la publicación. En su lugar encontramos un austero collage donde se lee "El arte no duerme" y la pequeña figura de un hombre caminando. Una de las notas principales del número - en cuya tapa hay una foto de la cantante pop Madonna-, a cargo de Marcela Calderón Durán, reseña el aporte de las realizadoras al campo audiovisual, contabilizando 36 obras — pero sin citar los títulos- y señalando las consabidas dificultades de financiación. Sin demasiados aportes críticos, recoge algunas opiniones entre las que sobresale la de Danielle Caillet quien afirma: "Estamos en una sociedad capitalista donde la remuneración económica 
CATEDRAL Tomada: Revista de crítica literaria latinoamericana / Journal of Latin American Literary Criticism Pequeña historia de un proyecto utópico: el Movimiento del Nuevo Cine y Video Boliviano y su Revista Imagen

determina que lo que tú hagas se llame trabajo o se llame hobby. El trabajo del video no deja remuneración alguna y por ello no se lo considera un trabajo serio" (Caillet en Calderón Durán 4). No se hace mención al sub-agrupamiento femenino dentro del Movimiento y ni de la red con otras videastas latinoamericanas; las imágenes que acompañan la nota nada tienen que ver con su contenido y corresponden a la actriz francesa Beatrice Dalle.

La segunda nota importante corresponde a la entrevista hecha al camarógrafo peruano Jorge Vignati quien había trabajado junto Jorge Sanjinés y Antonio Eguino: único enlace explícito con el audiovisual latinoamericano. Un aporte singular de este número se ve en la contratapa donde aparece un cuestionario común que, en pos de abrir la discusión sobre la fisonomía, figuras y problemas de la TV nacional, se le realizara a cuatro miembros del campo audiovisual boliviano: desde su experiencia personal, opinan Roger Cortez (productor y presentador televisivo), Hugo Ara (Secretario ejecutivo de la Conferencia Episcopal de Bolivia y videasta), Danielle Caillet (fotógrafa y realizadora) y César Pérez (cineasta, director de fotografía y camarógrafo).

El último número de Imagen sale más de un año después y corresponde a los meses de julio-agosto de 1991: se vuelve al formato carta, pero la revista sigue siendo breve, ya no hay corresponsales ni colaboradores, no se cuenta con los auspicios institucionales ni anuncios publicitarios. Hay cambios importantes en el equipo: aunque el director sigue siendo Eiffel, el consejo editorial pasa a conformarse nuevamente sin división de roles y lo componen Diego Torres, Marcos Loayza y Fernando Prado. En los créditos se lee una aclaración nunca antes consignada: "Publicación del Movimiento del Nuevo Cine y Video Boliviano. Gestión 1990-1991". ${ }^{29}$ En efecto, al final del número figura la nómina de los miembros de la nueva CE/directorio: en junio de ese año se eligieron a Iván Sanjinés, como secretario ejecutivo; Francisco Cajías como Secretario de Relaciones Internacionales; y Jean Claude Eiffel como Secretario de Relaciones Nacionales.

${ }^{29}$ El subrayado es nuestro. 
CATEDRAL TOMADA: Revista literaria latinoamericana / Journal of Latin American Literary Criticism María Gabriela Aimaretti

La portada —que venía optando por imágenes de la cultura masivavuelve a centrarse en referencias locales, en este caso el rostro de Ruth Pozo, actriz coprotagónica de la telenovela boliviana "Larga Distancia" dirigida por Eduardo Ascarruz, y una fotografía más pequeña que registra una marcha en reclamo por la Ley de Cine (una mujer con estandarte y manifestantes con banderas). Se lee en el editorial:

Hay dos grandes motivos para que este retorno se haya producido: la indiscutible necesidad de que éste medio de comunicación especializado continúe aportando al desarrollo de la producción audiovisual en nuestro país, y el contribuir decididamente a la campaña por la aprobación de la ley del cine que se reinicia al comenzar una nueva legislatura bajo el lema: No renunciaremos. ¡Ley de cine ya! (Imagen, Editorial XI 2).

Aunque ninguno de los entrevistados hizo mención puntual al respecto, de la nota en los créditos y el editorial puede inferirse que la demora en la salida de la revista en este caso pudo haber obedecido a que, a falta de recursos económicos y humanos — pues poco a poco el Movimiento se iba dispersando-, la gestión anterior considerase necesario suspender la edición de Imagen. Por su parte, es muy probable que el nuevo directorio, frente a la coyuntura ligada a la Ley del Cine, para darle mayor difusión al reclamo y reimpulsar al MNCVB en las actividades del sector, la hubiera elegido nuevamente como tribuna de debate y plataforma de acción.

En coherencia con el editorial, el núcleo temático del último número es el estado actual de la producción audiovisual (cine, video y TV), sus actores y grado de autocrítica; así como la participación activa o pasiva, según el caso, de miembros del sector en relación a la lucha por la Ley Nacional de Cine. Son artículos breves, cargados de ironía, de propuesta — se demanda más audacia temática, más constancia, más profesionalismo, actualización constante-; o de duro diagnóstico, como el de Susz quien señala: "Un factor de considerable importancia me parece ser la menguada predisposición reflexiva que acompaña al espontaneísmo del hacer con mucha euforia, y no pocas pretensiones, pero sin 
CATEDRAL Tomada: Revista de crítica literaria latinoamericana / Journal of Latin American Literary Criticism Pequeña historia de un proyecto utópico: el Movimiento del Nuevo Cine y Video Boliviano y su Revista Imagen

admitir el intercambio de ideas para averiguar hacia donde se apuntaba en definitiva (...) Aspecto en el cual el MNCVB estaba llamado a jugar un papel definitorio al que faltó sin aviso. La ausencia todavía es salvable (Susz, El dedo en el 4).

Asimismo, una nota sin firma - que suponemos es producto de las plumas de Eiffel y Susz- detalla qué es la Ley, quiénes participaron de la redacción del proyecto, cuáles son sus objetivos, a quiénes beneficiaría y quiénes la apoyan, denunciando a su vez que "una deliberada campaña de distorsiones, tergiversaciones y mentiras ha buscado confundir a la opinión publica acerca de los verdaderos propósitos y contenidos del Proyecto de Ley" (S/D, No renunciamos 11). El texto va acompañado de varias fotos que testimonian la movilización social alrededor del reclamo y festivales artísticos a beneficio de la molecularización de la demanda — se advierte un cartel que sentencia: "País sin imagen propia. País ajeno". Efectivamente en 1991 se va a debatir y aprobar la Ley de Cine. Según Eiffel y Eduardo López, ${ }^{30}$ conseguir ese triunfo tan ansiado y demorado provocó la dispersión de voluntades y energías tanto dentro del Movimiento como dentro del proyecto de la revista, de la cual el primero se desvinculó ese mismo año al igual que del Movimiento debido a nuevas inquietudes profesionales y crecimiento personal. ${ }^{31}$

Casi como volviendo al inicio, un epílogo artesanal nos trae nuevamente un Boletín Imagen, "suplemento" de la revista del MNCVB: aparentemente la publicación no volvió a salir pero sí este pequeño folleto fotocopiado de cuatro carillas y de tamaño oficio. Aunque no se consignan más datos al respecto, el titular de la tapa, con acompañamiento de dos imágenes -una de los pioneros del mudo, y otra de Susz-, exclama la victoria: "Mujeres y hombres al borde un ataque de nervios. Pero la conseguimos. El MNCVB agradece a todos los que se

${ }^{30}$ Entrevista personal, agosto-septiembre 2017.

${ }^{31} \mathrm{El} \mathrm{N}{ }^{\circ} 11$ cuenta además con un texto teórico sobre guión, escrito por Jean Claude Carriere, traducido por la revista y perteneciente al libro de entrevistas compilado por Christian Salé "Les scenaristes au travail" - Los guionistas trabajan- (1981); y una columna sobre la nueva película en preparación del Grupo Ukamau, Para recibir el canto de los pájaros, en la sección "Producción nacional". 
movilizaron para obtener la..... LEY DEL CINE. Y a Pedro Susz por la gran batalla ganada”. Sin fecha, suponemos que el Boletín corresponde a la gestión que asume a fines de 1991, encabezada por Francisco Cajías, como secretario ejecutivo. Angelino Jaimes, figura como secretario permanente; y Jaimes y Marcos Loayza como diagramadores. El Boletín es fundamentalmente informativo, divulgando futuros concursos y convocatorias, festivales y muestras, y anunciando que en el próximo número se comentará "Todo sobre Coroico", en alusión al encuentro departamental de cine y video a realizarse en 1992. Pero ese número de Imagen nunca llegó a imprimirse. ${ }^{32}$

\section{Contratapa (a manera de conclusión)}

Como dijimos anteriormente, la emergencia y sostenibilidad de la Revista Imagen deben ponerse en relación con la serie de emprendimientos editoriales previos concretados desde mediados de los setenta: se había construido un pequeño mercado, consolidado un grupo de intelectuales en diálogo, un sector de lectores activos y un territorio de discusión. Sobre ese suelo se irguió Imagen: interpelando a la generación anterior — que aprovechó muy bien esas páginas para intervenir y dar a conocer sus puntos de vista basados en una sólida experiencia previa- y a los propios pares - muchos de los cuales publicaron sus primeros textos/ensayos críticos, teóricos e históricos. Lamentablemente, tras el período de desarrollo de la revista no volvió a contarse en Bolivia con un vigor semejante en lo que hace a producción bibliográfica o de publicaciones periódicas sobre cine; ni tampoco con espacios de diálogo y colaboración entre diferentes generaciones.

$\mathrm{Si}$ bien los sentidos generales fundacionales de Imagen se mantuvieron durante toda su trayectoria - esto es, ser un instrumento de comunicación, información, conocimiento recíproco y formación-; a partir de las modificaciones

32 Ninguno de los/las entrevistados/as supo decir exactamente cuál fue el último número de la revista, ni siquiera su director. Con todo, la Cinemateca Boliviana guarda la misma cantidad de ejemplares que hemos comentado. 
CATEDRAL TOMADA: Revista de crítica literaria latinoamericana / Journal of Latin American Literary Criticism Pequeña historia de un proyecto utópico: el Movimiento del Nuevo Cine y Video Boliviano y su Revista Imagen

en la línea editorial y los cambios de énfasis de la publicación, que además coinciden con las renovaciones en el equipo de trabajo y el formato, es posible establecer una micro-periodización de tres momentos.

El primero se corresponde con la salida del Boletín inicial y los cuatro primeros números, entre julio de 1986 y octubre de 1987. En este ciclo que dura aproximadamente un año y cuatro meses, se observa una doble vocación: difundir las tareas de colegas latinoamericanos, consolidando enlaces, solidaridades y afinidades identitarias; y fortalecer las acciones del Movimiento visibilizando sus acciones en el espacio audiovisual local. Muchos de sus miembros intervienen activamente en pensar y difundir la revista y escriben en ella, debatiendo con reconocidos colaboradores externos. El staff de trabajo es prácticamente masculino y no hay división de roles. Se trata de un tiempo de entusiasmo, efervescencia y experimentación donde no faltan el humor y la creatividad, contrarrestando los magros recursos disponibles para la diagramación y el diseño. Es un momento con énfasis corporativo, de explícito tono político, progresista, en el cual se subraya la responsabilidad del videasta respecto de la representación de las "mayorías nacionales" y la "realidad del país"; así como también respecto del diálogo con los espectadores, tan saturados de discursos y producciones de la cultura norteamericana.

Entre el primer y segundo momento media un año y dos meses, donde la revista no se imprime. Entre diciembre de 1988 y julio de 1989, se extiende el segundo ciclo de Imagen, correspondiendo con la salida de los números 5, 6 y 7. En este período de ocho meses se observa la voluntad por convertirla en una publicación de mayor alcance, tanto en lo que refiere a cantidad de lectores como al cuerpo de colaboradores que sufre un crecimiento exponencial en términos cuantitativos y cualitativos, incluyendo columnistas de otros departamentos y países, y mayor presencia femenina. Incluso en este momento se abre un espacio para que "los lectores" se pronuncien: si bien la intención era genuina, lo cierto es que ese pequeño espacio fue ocupado por la polémica entre dos críticos, y no por lectores ordinarios. En este ciclo, el equipo de trabajo se estabiliza, se discriminan 
roles precisos y la organización de los contenidos es más convencional y general, y menos "conceptual". Recuérdese que en el período anterior a partir del nombre de la revista se diagramaron el resto de las secciones: Primer Plano, Imagen en Movimiento, Imagen Latinoamericana... etc., lo cual contribuyó a instalar una marca, un concepto integral e integrador para la publicación. A esta altura, las proyecciones e intereses se expandieron: se socializaron aportes teórico-prácticos para usos didácticos en el aprendizaje de distintos campos técnicos, e incluso se dio lugar a la reseña y discusión de manifestaciones de cine mundial sin la preeminencia de lo latinoamericano. De ahí la inclusión de otras iconografías y la diversificación del repertorio visual y estilístico. En suma, es un momento de estabilización y consolidación, moderación de la línea política previa, búsqueda de pluralidad discursiva y flexibilización — aunque sea en términos nominalesdel horizonte paceño sectorial.

Mediando la segunda y la tercera etapa transcurren nueve meses. Ésta última se extiende desde abril a mayo de 1990 y dura apenas dos meses, correspondiendo con la salida de los números 8, 9 y 10. Es el período de mayor austeridad y reducción de recursos, donde el tema central es la demanda por la Ley Nacional de Cine: la revista ya no ofrece información sobre el Movimiento Latinoamericano de Videastas y da muy pocos datos del MNCVB, hay un predominio de imágenes de la cultura masiva y, debido a una menor extensión, se pierde profundidad analítica. Sin embargo y pese a todo, no deja de salir a la calle. Tras estos tres momentos de mediana extensión y un silencio de catorce meses, la publicación finaliza con una suerte de epílogo. Un breve tiempo que se extiende entre julio de 1991 y finales de año, que se corresponde con la salida del No 11 y el último Boletín, donde se profundiza y exalta la necesidad de discutir y luchar por una Ley propia: un momento donde se augura un nuevo comienzo, que sin embargo no termina de cuajar. De hecho, no es menor la salida de Eiffel del proyecto: de alguna manera, la desvinculación de quien fue el único miembro estable durante toda la trayectoria de la revista, su impulsor, promotor y animador más constante, marcaría el final de Imagen. 
CATEDRAL TOMADA: Revista de crítica literaria latinoamericana / Journal of Latin American Literary Criticism Pequeña historia de un proyecto utópico: el Movimiento del Nuevo Cine y Video Boliviano y su Revista Imagen

En efecto, este órgano de discusión, organización y articulación que contagió el deseo de producir nuevas imágenes en movimiento respecto de la Bolivia contemporánea ya no únicamente en La Paz sino en otros departamentos y dio a conocer el Movimiento a la sociedad local y a otras comunidades de cineastas y videastas del Cono Sur, fue apagándose poco a poco. Según Iván Sanjinés: “[...] era una manera concreta de estar vivos, de existir". Por eso, a medida que el Movimiento fue transformándose y perdiendo buena parte de su formación inicial, la Revista Imagen, que emanó de las inquietudes de esos miembros, también se fue diluyendo y perdiendo vitalidad.

Sin embargo, resulta insoslayable restituir su "imagen", su identidad y su valor intrínseco dentro de la historia del audiovisual boliviano, y más específicamente dentro del campo de producción de conocimiento sobre cine nacional y latinoamericano. Sitio sinérgico de encuentro entre distintas perspectivas -no siempre coincidentes-, oportunidad de pronunciamiento y ensayo de ideas propias de la joven guardia, y ámbito de reunión intergeneracional; cada número ofrece al historiador interesado una cantera de documentos sobre la vida, la sensibilidad, el pensamiento, las voces y visiones del espacio audiovisual vernáculo de la década de los ochenta. Brinda destellos de $s u$ imagen. Sin renunciar ni al humor ni a la profundidad analítica, la revista fue un emprendimiento que, nacido orgánicamente del actor social más activo del período -el MNCVB-, demostró constancia y creatividad haciendo de la escasez, fecundidad; y de la dificultad, creatividad.

\section{Bibliografía}

Aimaretti, María. "El aporte de las videastas documentalistas a la escena boliviana en el retorno democrático: sensibilidades, prácticas y discursos". Revista Cine Documental No 16, (2017): 1-27.

AA.VV. Cine Boliviano: del realizador al crítico. Carlos Mesa (coord.). La Paz: Gisbert, 1979. 
CATEDRAL TOMADA: Revista literaria latinoamericana / Journal of Latin American Literary Criticism María Gabriela Aimaretti

Calderón Durán, Marcela. “La mujer. Luz, cámara, mujer”. Revista Imagen No 10 domingo 27 de mayo (1990): 4-5.

Eiffel, Jean Claude. "Y ahora, para los niños...". Revista Imagen $\mathrm{N}^{\circ} 4$ septiembre -octubre (1987): 18-21.

"Charla con Jorge Sanjinés". Revista Imagen $N^{\circ} 8$ domingo 8 de abril (1990): 8-11.

Espinal, Luis. Conciencia crítica ante el cine. La Paz: Editorial Don Bosco, 1976.

Flores, María Teresa. "Décimo Cóndor de Plata". Revista Imagen No 1 noviembre-diciembre (1986): 8-10.

Gumucio Dagron, Alfonso y Asamblea Permanente de DD.HH. Lucho Espinal: el grito de un pueblo. Lima: CEP, 1981.

Gumucio Dagron, Alfonso Historia del cine boliviano. La Paz: Los amigos del libro, 1982.

Luis Espinal y el cine. La Paz: CIMCA-UMSA, 1986.

"El juguete bomba". Revista Imagen No 7 junio-julio (1989): 6-9.

Imagen "Editorial I". Revista Imagen No 1 noviembre-diciembre (1986): 1.

"Editorial II". Revista Imagen No 2 enero-febrero (1987): 1.

"Editorial III". Revista Imagen No 3 marzo-abril (1987): 1.

“Editorial IV". Revista Imagen No 4 septiembre-octubre (1987):1.

"Editorial V". Revista Imagen No 5 diciembre 1988 y enero (1989): 1.

"Editorial VI". Revista Imagen No 6 abril-mayo (1989): 1.

"Cartas". Revista Imagen $\mathrm{N}^{\circ} 6$ abril-mayo (1989): 3.

"Editorial VII". Revista Imagen No 7 junio-julio (1989): 1.

"Los que nunca fueron. Cuento inédito de Oscar Soria". Revista Imagen $\mathrm{N}^{\mathrm{o}}$

7 junio-julio (1989): 34-35

“Editorial VIII". Revista Imagen No 8 domingo 8 de abril (1990): 3.

"Editorial IX". Revista Imagen $N^{\circ} 9$ domingo 29 de abril (1990): 3.

"Editorial X". Revista Imagen No 10 domingo 27 de mayo (1990): 3.

"Editorial XI". Revista Imagen No 11 julio-agosto (1991): 1.

Lozada, Fernando. "Todo a la televisión privada a cambio de nada". Revista Imagen $\mathrm{N}^{\mathrm{o}} 3$ marzo-abril (1987): 3-7.

Mesa, Carlos. El cine boliviano según Luis Espinal. La Paz: Editorial Don Bosco, 1982.

"La comunicación social, su evolución y su reglamentación". Revista Imagen $\mathrm{N}^{\mathrm{o}} 3$ marzo-abril (1987): 32-39.

La aventura del cine boliviano. La Paz: Gisbert, 1985.

MNCVB. Boletín del Nuevo Cine y Video. Imagen. Año 1, No 1 julio (1986).

“1986: Un fructífero año para el MNCVB”. Revista Imagen Nº 2 (1987):

21-24

"Movimiento del Nuevo Cine y Video Boliviano". Revista Imagen № 3 marzo-abril (1987): 46.

"Video y producción nacional". Revista Imagen $\mathrm{N}^{\circ} 4$ septiembre-octubre (1987): 25-27.

"Encuentro latinoamericano de Video Cochabamba 89". Revista Imagen

$\mathrm{N}^{\circ} 6$ abril-mayo (1989): 40-41. 
CATEDRAL Tomada: Revista de crítica literaria latinoamericana / Journal of Latin American Literary Criticism

Pequeña historia de un proyecto utópico: el Movimiento del Nuevo Cine y Video Boliviano y su Revista Imagen

Petricevich, Andrés. "No importa qué se transmita, si es legal. Entrevista al Ministro de Transportes y Comunicaciones". Revista Imagen $\mathrm{N}^{\mathrm{o}} 4$ septiembre-octubre (1987): 12-14.

Pizarroso, Guido. "La TV como servicio publico". Revista Imagen $\mathrm{N}^{\mathrm{o}} 4$ septiembre -octubre (1987): 15-17.

Revista Film/ Historia No 1 mayo (1978).

Romero, Raquel y Liliana De la Quintana. "El video y las Nuevas Generaciones de Realizadores Bolivianos". Revista Contacto 25/26 enero (1988): 56-60.

Romero, Raquel. "1986: un fructífero año para el MNCVB". Revista Imagen $\mathrm{N}^{\circ} 2$ enero-febrero (1987): 21-24.

Sanjinés, Jorge y Grupo Ukamau. Teoría y práctica de un cine junto al pueblo. México: Siglo XXI, 1980.

Sanjinés, Jorge. "Una nueva perspectiva para el cinema". Revista Imagen $\mathrm{N}^{\circ} 9$ domingo 29 de abril (1990): 4-5.

$\mathrm{S} / \mathrm{D}$. "No renunciamos. Ley de Cine ya!". Revista Imagen $\mathrm{N}^{\mathrm{o}} 11$ julio-agosto (1991):10-11.

Susz, Pedro. La pantalla ajena. La Paz: Gisbert, 1985.

"Ser o no ser: para el audiovisual boliviano esa es también la cuestión". Revista Imagen $\mathrm{N}^{\circ} 6$ abril-mayo (1986): 4-9.

"El dedo en el ventilador". Revista Imagen No 11 julio-agosto (1991): 3-5

Torres, Diego. "Nuevo cine, atravesar el umbral". Revista Imagen $\mathrm{N}^{\circ} 2$ enerofebrero (1987): 38-39.

"Taller de cine de la UMSA. Una década de aportes y limitaciones". Revista Imagen $\mathrm{N}^{\mathrm{o}} 7$ junio-Julio (1989): 50-51.

"Cine de los 90". Revista Imagen $\mathrm{N}^{\circ} 9$ domingo 29 de abril (1990): 8-9. 